\title{
Congenital malformations associated with anencephaly and iniencephaly
}

\author{
T. J. DAVID* and ANGELA NIXON \\ From the Department of Child Health, Bristol Royal Hospital for Sick Children, Bristol, BS2 8BF
}

\begin{abstract}
Summary. The necropsy reports of 294 cases of anencephaly and 50 cases of iniencephaly have been examined, and a tabulated list of associated malformations produced. Cases were divided by sex and the presence or absence of spina bifida. Forty-one per cent of the series had other malformations, and other malformations were more common in those cases with spina bifida than in those without. The most frequent single malformations were: hydronephrosis $(8 \%)$, cleft palate $(8 \%)$, diaphragmatic hernia $(5 \%)$, exomphalos $(5 \%)$, hare lip $(4 \%)$, and horseshoe kidney $(4 \%)$. It is suggested that the presence of other malformations in anencephaly or iniencephaly may imply some aetiological heterogeneity.
\end{abstract}

Since anencephaly is a lethal malformation, the presence in some cases of other malformations does not seem to have attracted much interest. Indeed, with the exception of the Second Report of the British Perinatal Mortality Survey of 1958 (Butler and Alberman, 1969), it has not been possible to trace a fully tabulated list of associated malformations in a large necropsy series of anencephalics. Standard teratological texts such as Ballantyne (1904) and Warkany (1971) only briefly mention without giving any idea of their frequency the associated malformations. The explanation for these associated malformations may be so simple and obvious that it is hardly ever mentionedabnormal fetal growth at an early stage leading to other malformations. Ballantyne (1904) stated (referring to the pathogenesis of associated malformations in iniencephaly): 'Further ontogeny is hindered and cramped, and so the associated malformations (e.g. diaphragmatic hernia) arise'. Liggins (1974) went a little further than this when he wrote: 'The diversity of associated anomalies raises the possibility that the teratogenic influence responsible for the failure of the anterior extremity of the neural tube to develop has widespread effects, including reduction in cell number and consequent growth retardation. Determinations of cell number in anencephaly have not been reported.'

\footnotetext{
Received 22 August 1975.

* Present address: Musgrove Park Branch, Taunton and Somerset Hospital, Taunton, Somerset, TA1 5DA.
}

A study of diaphragmatic hernia (David and Illingworth, 1976) showed a strong association between diaphragmatic hernia and both anencephaly and iniencephaly. An interest in the reverse association prompted the present study, a simple systematic review of malformations in patients with anencephaly or iniencephaly.

\section{Subjects and methods}

The cases were all born in the Bristol region, and were ascertained through the necropsy diagnostic index compiled by Dr N. J. Brown, consultant pathologist, at Southmead Hospital. The necropsy records of all cases listed under the headings of anencephaly and iniencephaly from 1948 to 1975 were studied. Four cases of anencephaly were excluded because a full necropsy had not in fact been performed, leaving 294 cases of anencephaly and 50 cases of iniencephaly.

\section{Results}

The associated malformations are given in the Table, with the cases subdivided by sex and by the presence or absence of spina bifida. The following were not included as malformations: changes in the size of the adrenals, the thymus, the thyroid or the pituitary; club foot; hypoplasia of the lungs; high arched palate.

The seven 'genital' defects were: hypospadias with penile hypoplasia (1); hypoplastic penis (2); very hypoplastic testes (1); absent left Fallopian 
TABLE

ASSOCIATED MALFORMATIONS IN 294 CASES OF ANENCEPHALY AND 50

\begin{tabular}{|c|c|c|c|c|c|c|c|}
\hline & $\underset{\mathrm{AC}+\mathrm{SB}}{\text { Male }}$ & $\begin{array}{c}\text { Male } \\
\text { AC } \\
\text { only }\end{array}$ & $\begin{array}{c}\text { Female } \\
\text { AC + SB }\end{array}$ & $\begin{array}{c}\text { Female } \\
\text { AC } \\
\text { only }\end{array}$ & $\underset{\text { IC + SB }}{\text { Male }}$ & 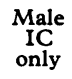 & $\begin{array}{r}\text { Female } \\
\text { IC + SB }\end{array}$ \\
\hline $\begin{array}{l}\text { Horseshoe kidney } \\
\text { Hydronephrosis } \\
\text { Polycystic kidney } \\
\text { Absent kidney (unilateral) } \\
\text { Absent kidney (bilateral) } \\
\text { Hypoplastic kidney (unilateral) } \\
\text { Urethral atresia } \\
\text { Oesophageal atresia } \\
\text { Meckel's diverticulum } \\
\text { Multiple spleens } \\
\text { Situs inversus } \\
\text { Malrotation } \\
\text { Other gastrointestinal malfs. } \\
\text { Exomphalos } \\
\text { Diaphragmatic hernia } \\
\text { Lung-defects } \\
\text { Hare lip } \\
\text { Cleft palate } \\
\text { Cardiovascular malformations }\end{array}$ & $\begin{array}{l}1 \\
0 \\
0 \\
1 \\
1 \\
0 \\
1 \\
0 \\
0 \\
1 \\
0 \\
0 \\
1 \\
4 \\
2 \\
0 \\
2 \\
5\end{array}$ & $\begin{array}{l}1 \\
5 \\
2 \\
0 \\
0 \\
1 \\
0 \\
0 \\
0 \\
0 \\
0 \\
0 \\
0 \\
0 \\
0 \\
0 \\
2 \\
6\end{array}$ & $\begin{array}{l}5 \\
9 \\
4 \\
0 \\
0 \\
2 \\
0 \\
0 \\
1 \\
2 \\
1 \\
5 \\
1 \\
3 \\
5 \\
2 \\
2 \\
5\end{array}$ & $\begin{array}{r}0 \\
11 \\
1 \\
1 \\
1 \\
1 \\
1 \\
1 \\
1 \\
0 \\
0 \\
1 \\
3 \\
0 \\
3 \\
1 \\
1 \\
3 \\
5\end{array}$ & $\begin{array}{l}0 \\
1 \\
0 \\
0 \\
0 \\
0 \\
0 \\
0 \\
1 \\
0 \\
0 \\
0 \\
1 \\
0 \\
1 \\
0 \\
0 \\
0\end{array}$ & $\begin{array}{l}0 \\
0 \\
0 \\
0 \\
0 \\
0 \\
0 \\
0 \\
0 \\
0 \\
0 \\
1 \\
0 \\
0 \\
0 \\
0 \\
0 \\
0\end{array}$ & $\begin{array}{l}5 \\
3 \\
1 \\
2 \\
0 \\
1 \\
0 \\
0 \\
0 \\
0 \\
1 \\
1 \\
1 \\
4 \\
4 \\
2 \\
2 \\
4\end{array}$ \\
\hline $\begin{array}{l}\text { (excluding single umbilical artery) } \\
\text { Single umbilical artery } \\
\text { Cyclopia } \\
\text { Skeletal defects } \\
\text { Genital defects } \\
\text { Absent pinna } \\
\text { Inguinal hernia } \\
\text { Twin* }\end{array}$ & $\begin{array}{l}2 \\
1 \\
0 \\
0 \\
1 \\
0 \\
0 \\
1\end{array}$ & $\begin{array}{l}1 \\
0 \\
0 \\
3 \\
1 \\
0 \\
1 \\
1\end{array}$ & $\begin{array}{l}3 \\
0 \\
0 \\
0 \\
0 \\
0 \\
0 \\
1\end{array}$ & $\begin{array}{l}\mathbf{5} \\
\mathbf{5} \\
\mathbf{0} \\
\mathbf{2} \\
0 \\
\mathbf{0} \\
\mathbf{0} \\
\mathbf{5}\end{array}$ & $\begin{array}{l}1 \\
0 \\
0 \\
0 \\
1 \\
1 \\
0 \\
0\end{array}$ & $\begin{array}{l}0 \\
0 \\
0 \\
1 \\
1 \\
0 \\
0 \\
0\end{array}$ & $\begin{array}{l}2 \\
4 \\
1 \\
0 \\
1 \\
0 \\
0 \\
0\end{array}$ \\
\hline Cases with no other defects & 19 & 25 & 61 & 91 & 0 & 2 & 6 \\
\hline Totals & 33 & 40 & 103 & 118 & 9 & 4 & 27 \\
\hline
\end{tabular}

AC: Anencephaly SB: Spina bifida IC: Iniencephaly

* Twinning was not counted as a malformation but is included in this table for interest.

tube (1); absent right Fallopian tube and ovary (1); bicornuate uterus (1).

The 17 cardiovascular system defects were: transposition of the great vessels (3); Fallot's tetralogy (3); coarctation of the aorta (2); hypoplastic left heart (2); ostium primum atrial septal defect plus ventricular septal defect (1); secundum atrial septal defect (1); cor biloculare and absent pulmonary artery (1); right-sided aortic arch (1); truncus arteriosus, atrial septal defect, ventricular septal defect, atresia of left pulmonary artery (1); single ventricle (2).

The five other gastrointestinal defects were: absent gall bladder (1); reduplication of the ileum (1); extra-hepatic biliary atresia with absent gallbladder (1); ectopic anus (1); rectal atresia (1).

The seven skeletal defects were: radial club hands (1); absent left big toe (1); polysyndactyly (1); extra right thumb (1); bowed tibiae (1); absent right thumb (1); right radial club hand (1).

\section{Discussion}

Females outnumbered males by exactly three to one in this series, a sex ratio of 0.33. As for the associated malformations, the principal sex differences were for cleft palate and genital anomalies (commoner in males), and single umbilical artery and malrotation (commoner in females). Females were less likely to have an associated malformation.

Forty-one per cent of the series had other malformations (i.e. outside the nervous system). Associated malformations were more common in those cases with spina bifida $(50 \%)$ than in those without spina bifida (31\%). Exactly half the cases had spina bifida in addition to either anencephaly or iniencephaly. Eighty-four per cent of iniencephalics had other malformations.

The urinary tract was the most frequently affected system, urinary defects occurring in $19 \%$ of cases. This is followed by the cardiovascular and gastrointestinal systems each being affected in $8 \%$ of cases. The most frequent single malformations were, in order, hydronephrosis $(8 \%)$, cleft palate (8\%), diaphragmatic hernia (5\%), exomphalos $(5 \%)$, hare lip (4\%), and horseshoe kidney (4\%).

Certain defects tended to affect the same side. All the diaphragmatic hernias were left-sided except for one bilateral case. All but one of the unilaterally absent kidneys were left-sided, and all but two of the unilaterally hypoplastic kidneys were left-sided. Of the six lung defects, five were a bilobed right lung and the sixth was an absent right lung.

Of what significance are associated malformations 
CASES OF INIENCEPHALY

\begin{tabular}{|c|c|c|c|}
\hline $\begin{array}{c}\text { Female } \\
\text { IC } \\
\text { only }\end{array}$ & All Female & All Male & Total \\
\hline $\begin{array}{l}0 \\
0 \\
1 \\
1 \\
1 \\
1 \\
0 \\
0 \\
0 \\
1 \\
0 \\
1 \\
1 \\
4 \\
4 \\
1 \\
2 \\
2\end{array}$ & 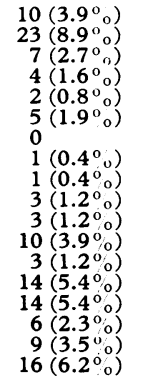 & 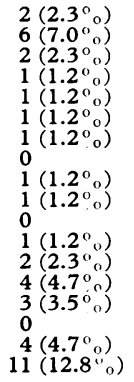 & 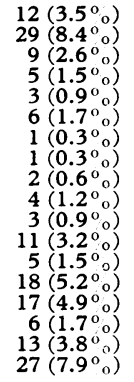 \\
\hline $\begin{array}{l}3 \\
1 \\
0 \\
1 \\
2 \\
0 \\
0 \\
0\end{array}$ & $\begin{array}{l}13(5.0 \%) \\
10(3.9 \%) \\
1(0.4 \% \%) \\
3(1.2 \% \%) \\
3(1.2 \% \%) \\
0 \\
0 \\
6(2.3 \%)\end{array}$ & $\begin{array}{l}5\left(5.8^{\circ}{ }^{\circ}\right) \\
1\left(1.2^{\circ}{ }_{0}\right) \\
0 \\
4\left(4.7^{\circ}{ }^{\circ}\right) \\
4\left(4.7{ }^{\circ}{ }_{0}\right) \\
1\left(1.2^{\circ}{ }_{0}\right) \\
1\left(1 .{ }^{\circ}{ }^{\circ}\right) \\
2\left(2.3^{\circ}{ }_{0}{ }_{0}\right)\end{array}$ & 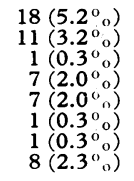 \\
\hline 1 & $159\left(61.6^{\circ}{ }_{0}\right)$ & $46\left(53.5^{\circ}{ }_{0}\right)$ & $203\left(59.0_{0}^{\circ}\right)$ \\
\hline 10 & 258 & 86 & 344 \\
\hline
\end{tabular}

in anencephaly and iniencephaly? It is not difficult to understand that the presence of a major defect such as anencephaly could impair embryonic growth and development, though the way certain structures are selectively affected suggests that this is not merely a non-specific effect of poor growth. It seems at least conceivable that a genetic predisposition which lays the fetus bare to various teratogens causing anencephaly could also predispose the fetus to the action of other teratogens. Certainly the limited range and characteristic pattern of malformations excludes a random association. However, it is difficult to envisage that these associated malformations stem from a single localized anomaly resulting in a 'cascade' of defects, as for example, in the Pierre Robin syndrome (Hanson and Smith, 1975; Smith, 1975). The exception would perhaps be the association of cleft palate; this probably is a simple developmental sequence that stems from the high position of the palatine raphe relative to the lateral palatine processes (Potter, 1961). It should be noted that anencephaly, with or without other malformations, can occasionally be associated with chromosome abnormalities, though exactly how frequent this is has not been established with the new banding techniques (Wright, Clark, and Breg, 1974; Schmid et al, 1975).

The literature on iniencephaly is cautious on the relation between it and anencephaly. However, it shares a female preponderance with anencephaly, it is apparently commoner in areas where anencephaly is common (Warkany, 1971), and it is often accompanied by spina bifida. Gardner (1973) regarded iniencephaly as 'ruptured anencephaly', this being part of his theory that rupture of the neural tube is the pathogenic mechanism in neural tube defects (rather than failure of the tube to close). For the purposes of genetic counselling iniencephaly seems to be treated as a neural tube defect.

It is concluded that in the same way that there are epidemiological and aetiological differences between spina bifida and anencephaly, so it is possible that anencephaly itself may consist of more than one aetiologically distinct entity. Further investigation will be needed to see if the different associated malformations in anencephaly correspond with different epidemiological variables or different genetic patterns.

This study would not have been possible without the detailed records made by Dr N. J. Brown, and we are indebted to him for his help. We are very grateful to Professor N. R. Butler for his help and encouragement.

\section{REFERENCES}

Ballantyne, J. W. (1904). Manual of Antenatal Pathology and Hygiene. Volume 2. The Embryo, pp. 272-284;347-348. William Green and Sons, Edinburgh.

Butler, N. R. and Alberman, E. D. (Eds.) (1969). Perinatal Problems. The Second Report of the 1958 British Perinatal Mortality Survey, plate 1 facing p. 304. Churchill Livingstone, Edinburgh. David, T. J., and Illingworth, C. A. (1976). Diaphragmatic hernia in the south-west of England. Fournal of Medical Genetics, 13, 253-262.

Gardner, W. J. (1973). The Dysraphic States. From Syringomyelia to Anencephaly, pp. 167-181. Excerpta Medica, Amsterdam.

Hanson, J. W. and Smith, D. W. (1975). U-shaped palatal defect in the Robin anomalad: developmental and clinical relevance. fournal of Pediatrics, 87, 30-33.

Liggins, G. C. (1974). The influence of the fetal hypothalamus and pituitary on growth. In Size at Birth, Ciba Foundation Symposium 27, pp. 165-183. Elsevier, Amsterdam.

Potter, E. L. (1961). Pathology of the Fetus and Infant, 2nd ed., p. 490. Year Book Medical Publishers, Chicago.

Schmid, W., Mühlethaler, J. P., Briner, J., and Knechtli, H. (1975). Ring chromosome 13 in a polymalformed anencephalic. Humangenetik, 27, 63-66.

Smith, D. W. (1975). Classification, nomenclature, and naming of morphologic defects. Fournal of Pediatrics, 87, 162-164.

Warkany, J. (1971). Congenital Malformations. Notes and Comments, pp. 189-200; 234-236. Year Book Medical Publishers, Chicago.

Wright, Y. M., Clark, W. E., and Breg, W. R. (1974). Craniorachischisis in a partially trisomic 11 fetus in a family with reproductive failure and a reciprocal translocation, $t(6 p+; 11 q-)$. fournal of Medical Genetics, 11, 69-75. 